VYTAUTAS PALEVIČIUS, Ph.D.

(Corresponding author)

E-mail: vytautas.palevicius@vgtu.It

VYTAUTAS GRIGONIS, Ph.D.

E-mail: vytautas.grigonis@vgtu.It

ASKOLDAS PODVIEZKO, Ph.D.

E-mail: askoldas@gmail.com

GRETA BARAUSKAITE், M.Sc.

E-mail: greta.barauskaitė @gtu.It

Vilnius Gediminas Technical University

Saulètekio al. 11, LT-10223 Vilnius, Lithuania
Intelligent Transport Systems (ITS)

Preliminary Communication

Submitted: Feb. 20, 2015

Accepted: Dec. 1, 2015

\title{
DEVELOPMENTAL ANALYSIS OF PARK-AND-RIDE FACILITIES IN VILNIUS
}

\begin{abstract}
A rapid growth in car ownership in the cities of Lithuania, particularly in Vilnius, has generated continuous traffic jams in the streets and thus has consequently increased negative transport impact and demand for financial and land resources. Also, a high level of car ownership requires large reserves of transport infrastructure. Therefore, it is necessary to create favourable conditions for creating sustainable urban transport infrastructure satisfying the needs of local inhabitants. Within the framework of the European Union Structural Assistance for the period 2014-2020, Vilnius city municipality administration is planning to submit an application to receive financial support for the implementation of the Park-and-Ride (hereinafter P\&R) scheme for Vilnius. The aim of the paper is to work out a multi-criteria methodology for selecting the sites of $P \& R$ lots and to carry out a developmental analysis of $P \& R$ facilities by creating the above introduced scheme for parking lots in the Vilnius City. The expert method has been used for utilizing a set of relevant criteria for planning the $P \& R$ scheme. With the help of the expert survey, the weights and significance of the defined criteria have been identified. Multi-criteria methods have been applied for calculating and presenting the developmental priorities and a strategy for the implementation of the offered proposals.
\end{abstract}

\section{KEY WORDS}

multi-criteria methods; P\&R scheme; planning urban infrastructure; public transport;

\section{INTRODUCTION}

Big cities are facing an increasing working and living pace, which can be hardly imagined without transport. One of the most pressing problems to be encountered by the inhabitants of large cities are related to the lack of parking spaces in the central part of the city. The present situation could be described as an issue caused by the processes of developing the urban transport system.
For the last 50 years, the transport system in the city has essentially changed. Around 1960, public transport was mainly the only way of communication in Vilnius and accounted for more than 95\%. Approximately 30 years later, a passenger car became the dominating vehicle, and 10 years afterwards, the importance of public transport decreased by $20-30 \%$. From 1981 to 2014, a number of cars increased more than 5 times. The reason for a growth in the level of car ownership is the policy of promoting passenger cars in the city. The consequences of the introduced developmental policy are changes in the way of life, demand for insatiable infrastructure, traffic jams, lack of parking spaces, etc.

An attempt was made to solve the shortage of parking spaces in Vilnius by building multi-storey, aboveground and underground parking lots. To accommodate a growth in traffic flow, streets were widened thus establishing a network of high-capacity driving areas, etc. The above mentioned decisions did not help with reducing the number of cars in the city but only brought to heavier consequences. The dominating original public transport systems in Vilnius (buses and trolleybuses) have gradually lost their priority. Changes in the way of life of inhabitants to make a door-to-door journey, reduction in the speed of public transport, accessibility, comfort and other features prompted to integrate transport systems into the processes of urban development planning [2; 3].

In 2012, Special Plan Solutions for Implementing New Transport Modes in Vilnius City were approved by the Vilnius City Council. The prepared document provides for the complex development of the transport system in Vilnius by combining public transport with the use of the P\&R scheme and other parts of the urban transport network.

Successful operation of the P\&R scheme depends on the integration of the transport system into the process of urban planning that assists in solving the 
issues of land ownership, identifying demand for financial resources and transport, assessing construction possibilities, etc. Planning P\&R schemes is affected by a number of local peculiarities and factors. Multi-criteria analysis reflects considerably better such local conditions and covers more practical criteria useful for preparing P\&R schemes. All in all, local transport experts possess excellent knowledge of local issues. The obtained information may lead to better suited solutions compared to fully automated methods based on transport criteria. From a methodological point of view and with reference to the above considerations, this paper could be a useful tool for Lithuanian as well as for foreign cities.

Therefore, the article is aimed at developing multi-criteria methodology for selecting P\&R parking sites and undertaking demonstrational analysis focused on the expansion of P\&R parking lots by creating a scheme for a similar type of facilities in Vilnius City. Thus, to achieve the goals of this work, the following tasks have been formulated:

1) Selecting quantitative and qualitative criteria having an impact on the development of P\&R parking lots.

2) Assessing and ranking quantitative and qualitative criteria and determining their significance.

3) Preparing a priority scheme for the implementation of P\&R parking lots in Vilnius City using multi-criteria decision support methods.

\section{LITERATURE REVIEW}

The P\&R scheme was launched in the USA in 1930 and concentrated on reducing traffic flows in the city centre [4]. As for Europe, the P\&R system was officially introduced in Great Britain in 1960. The proposed idea and scheme development were supported and encouraged by the Government aiming to reduce urban pollution and traffic flows.

At present, the P\&R system is being widely used in the major part of the EU cities such as Amsterdam (Holland), Warsaw (Poland), Hamburg (Germany), Prague (Czech Republic), London (Great Britain), Geneva (Switzerland), Florence (Italy), etc.

In 2008 the European Commission raised an objective to improve the quality of ambient air. The objective was presented in the Directive on Ambient Air Quality and Cleaner Air for Europe indicating it was appropriate to expand regulatory measures on the European scale by promoting interest in the development of innovations of potential sustainable transport (or transport policy) such as the P\&R scheme. Traffic congestions and air quality are a matter of great concern for urban planners; thus, the P\&R development model has been suggested as an element of sustainable urban development allowing people to use public transport $[3,5,6]$.
Dutch scientists made research in 25 European cities and discovered that the development of the P\&R scheme in the city reduced congestions and improved air quality. Also, they concluded that in the cities under consideration, congestions and air pollution could be reduced even more; however, there was lack of motivation from local authorities [7].

The analysis of the P\&R scheme in the EU cities shows that the implemented measures are not always effective. Therefore, researchers of the P\&R scheme seek to find the most rational alternative that would maximize the potential benefit of P\&R parking lots [8, $9,10,11]$. Scientists state that most drivers would use the services provided by the P\&R scheme only in case if the ratio between the journey by public transport and by passenger car was significantly different. This means that the services offered by the P\&R scheme must be fast and cheap while bus routes sufficiently frequent [12].

$P \& R$ variations or other strategies such as Kiss and Ride are used in case when drivers decide it would be beneficial for them to continue a part of the journey by public transport. A benefit could be expressed in terms of time or cost, or both of them. In 1979, the Consul of the United States on Environmental Issues reported that P\&R schemes would be beneficial if they were cheap enough and fast as driving a car [13].

Mingardo [14] singles out three categories of P\&R parking lots based on their site and distance:

1) Distant $P \& R$ parking lots. The scheme is intended for the people living in suburban areas and those encouraged to leave passenger cars in the P\&R parking lot and to continue their journey by public transport [15].

2) Peripheral $P \& R$ parking lots. The model of this scheme is typical of Great Britain and USA and is aimed at diverting passenger flows from terminal parking lots to the city centre [16].

3) Local P\&R parking lots focus on stopping drivers at the very beginning of their journey. Those are smaller lots situated beside the major transport corridors. The scheme is close to the Link and Ride concept [17].

P\&R parking lots basically bring more positive aspects into urban transportation systems, and therefore designing such schemes is a burning issue [18]. Unfortunately, there are not many recent research works and justification methods addressed to the development of new schemes for P\&R parking lots.

Farhan and Murray [19] proposed a multi-objective spatial optimization model specifying the objectives of coverage, travel time and existing facilities. One of the major advantages in this model is the possibility of planning $P \& R$ facilities in the context of the existing system; also, the extensions of this modelling approach could include other objectives. Khakbaz [20] developed a model for locating P\&R facilities on urban 
networks based on genetic algorithms and included a number of transportation-based aspects like travel demand, distance, travel time using a personal car or public transport, etc. At a later stage, for further research, the authors proposed to involve a multi-objective function. Fan [21] prepared a model with the capability to capture interactions between decision makers and commuters. The obtained results have revealed that adopting social welfare maximization as the optimization objective leads to a win-win outcome for both P\&R service providers and users.

Multi-criteria decision methods are designed to help decision makers in framing more clearly the problem and making better choices when facing complex decisions that may involve several dimensions. Such methods can help with identifying the values of stakeholders and undertaking a more disciplined and transparent analysis of options and their likely outcomes. They are especially helpful when there is need to combine objective information with subjective preferences (i.e. users of parking lots), to find a compromise between different objectives and to involve multiple decision makers. The advantages of this approach stem from its simplicity and practical approach.

Two broad categories of evaluation methods are known: qualitative and quantitative analysis. Qualitative analysis is based solely on expert's (or manager's) intuitive judgement. Qualitative analysis is not suitable for complex problems, and was consequently rejected. Statistical quantitative analysis methods require large quantities of data. Moreover, special attention should be paid to the normality or at least symmetry of distribution of data. In the case of a middle-sized city as Vilnius obtaining large quantities of data or large quantities of alternatives for collection of qualified panel data is hardly possible. Multi-criteria evaluation deals well with such cases, when evaluation is complex, and there are only a few alternatives to choose from. Most probably, these are major causes, why such methods are gaining popularity starting from the 1980s.

The proposed approach of the authors is based on the multi-criteria method that enables analysing the problem from a slightly different perspective than that discussed in the previous studies, i.e. to seek a systematic multi-objective approach form the point of urban and transport planning. The strength of the approach is the capability to employ knowledge of local experts, use quantitative and qualitative criteria, determine the significance of such criteria and include a full scale of very practical criteria. And last but not least, the authors developed a set of criteria based on the expert opinion, and such a system of criteria can be useful for further development of other already discussed methods.

\section{RESEARCH METHODOLOGY}

\subsection{Survey of Vilnius City inhabitants on identifying the encountered problems}

The research methodology of the P\&R scheme for Vilnius City is based on a survey of inhabitants, expertise and expert methods.

In the first stage, the survey of local inhabitants was carried out to identify complex and most relevant sectors in Vilnius city. Representative survey of Vilnius residents (18 years and older) were conducted during telephone interviews (CATI survey). Distribution of the respondents by gender, age, education and ethnicity corresponds to the distribution of Vilnius population according to these characteristics. The survey was conducted questioning 507 respondents and took place in January (7-29) 2010 (Figure 1).

Statistical error of the survey does not exceed $\pm 4.5 \%$ with the statistical reliability of the solution

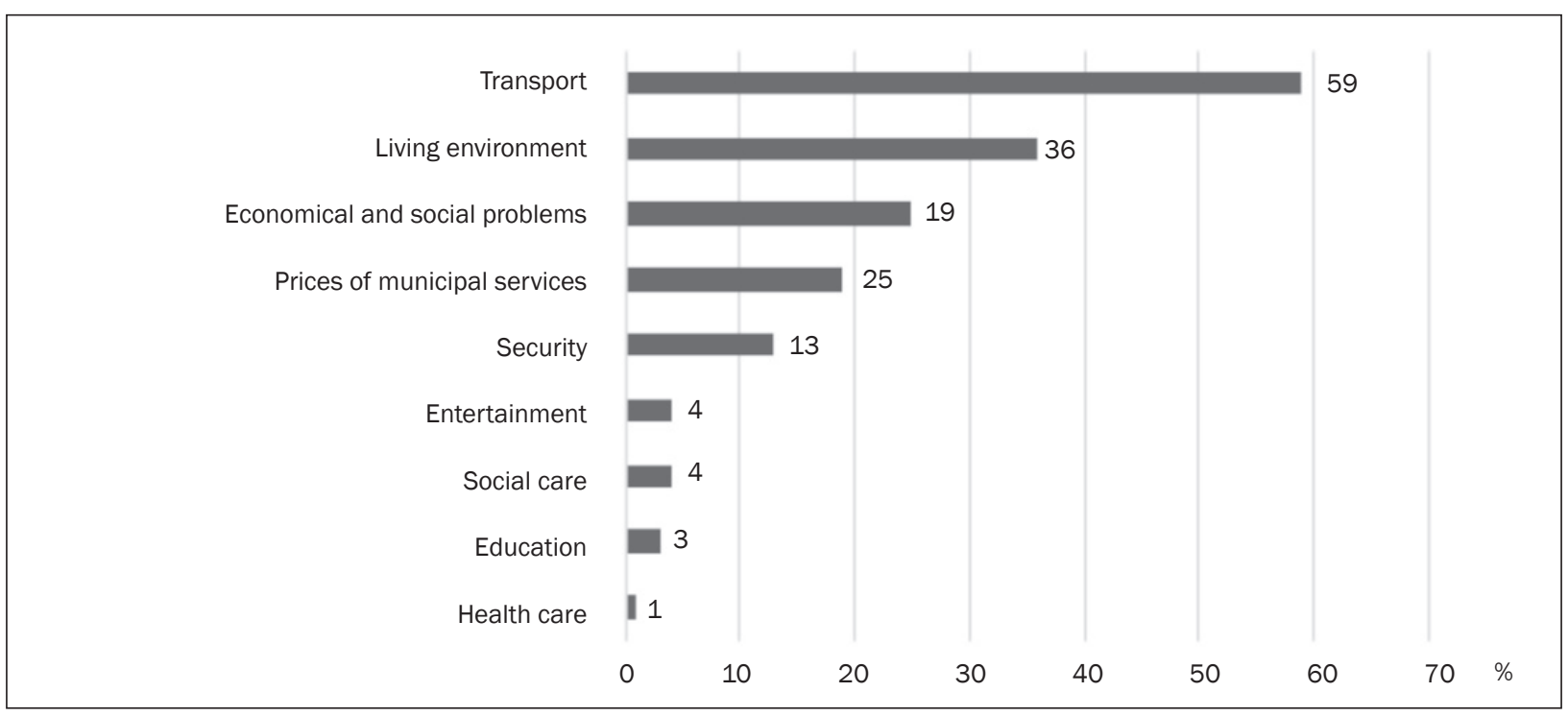

Figure 1 - Relevance of problems in Vilnius City 
95\%. Additional quality control audited approximately 10 per cent of interviews. Transport and communication sector (59\%) have been found the most topical and relevant sector for the largest share of the Vilnius population.

Compared to 2006, the major issue, as regards the opinion of city dwellers, still remains the disadvantages of the transport system and traffic jams in the streets (in 2006 - 51\%, in 2010 - 59\%). The displayed tendency shows that the above introduced question has been gaining more and more weight, and therefore it is necessary to take appropriate measures for solving it.

\subsection{Sampling criteria for selecting sites for P\&R parking lots}

The development of the P\&R scheme has been determined by a number of economic, social, urban and other factors that lack information to be properly evaluated. Expert methods utilize the knowledge of experienced professionals in evaluating the complexity of factors in a particular field.

In order to summarize the identified factors and to select the main criteria having an impact on the implementation of the P\&R scheme, a group of qualified experts was formed. The group consisted of practitioners and researchers having at least ten-year experience in the field of spatial planning of transport [22]. Primary selection of criteria was identified during literature review. Detailed selection of criteria involved participation of the group of experts with excellent understanding of the purpose of the research. Researchers had to compromise (expertise) between choosing a large number of criteria, units of measurement and data availability; therefore, the criteria meeting such compromise were chosen. The following list of criteria has been made: $\mathrm{K}_{1}$ - land price $(€ / 1,000 \mathrm{~m} 2)$ and construction cost $\left(€ / 1,000 \mathrm{~m}^{2}\right)$ of the $\mathrm{P} \& \mathrm{R}$ parking lot, $\mathrm{K}_{2}$ - traffic volume in the street beside the P\&R parking lot, $\mathrm{K}_{3}$ - the number of public transport routes during the peak hour, $\mathrm{K}_{4}$ - accessibility to the centre of Vilnius City by public transport $(\mathrm{km} / \mathrm{h}), \mathrm{K}_{5}$ - the safety of the P\&R parking lot (3-safe, 2-moderately safe, 1-unsafe), K6 - information system for informing drivers about free space (2-present, 1-absent), $K_{7}$ - a parking fee in the $P \& R$ parking lot $(€), K_{8}$ - the entrance to the $P \& R$ parking lot by passenger cars (2-safe, 1-unsafe), $K_{9}-$ street category defined by the width of the street $(\mathrm{m})$, $\mathrm{K}_{10}$ - an integrated ticket fee for using a passenger car and public transport $(€)$ and $\mathrm{K}_{11}$ - housing intensity planned in the Vilnius City Master Plan (\%).

The initial literature review has found that a large part of studies are using complex criteria with extra need of studies and numerical values of such criteria are obtained after calculations. Therefore, the authors have developed $P \& R$ criteria system, which is compre- hensible for the scientists and practitioners. The first set of criteria was created after a thorough literature review, i.e. five $\left(\mathrm{K}_{2}, \mathrm{~K}_{3}, \mathrm{~K}_{4}, \mathrm{~K}_{7}, \mathrm{~K}_{8}\right)$ criteria were derived after literature review $[5,10,12,21]$ and the rest $\left(K_{1}\right.$, $\mathrm{K}_{5}, \mathrm{~K}_{6}, \mathrm{~K}_{9}, \mathrm{~K}_{10}, \mathrm{~K}_{11}$ ) were selected on the basis of the authors' opinion. The final set was approved by the experts who participated in the evaluation, as per usual practice of the multi-criteria evaluation.

The list of the main criteria has been made depending on statistical data that could be used for mathematical calculation and, later, for determining the priority order of P\&R parking lots.

\subsection{Sites for implementing P\&R parking lots in the Vilnius City Master Plan}

Solutions for the Vilnius City Master Plan indicate 33 preliminary sites for the development of P\&R parking lots.

On the basis of the suggested plan, the authors divided P\&R parking lots into three groups:

1) Group I consists of 14 P\&R lots planned to be implemented in the peripheral zone of Vilnius City (criteria values are given in Table 1 ).

2) Group II consists of 13 P\&R lots planned to be implemented in the middle zone of Vilnius City (criteria values are given in Table 2).

3) Group III consists of 6 P\&R lots planned to be implemented in the central part of Vilnius City (criteria values are given in Table 3).

\section{MULTIPLE CRITERIA EVALUATION}

\subsection{Determining significance of criteria for P\&R parking lots}

With reference to ranking, the experts have determined weights of the criteria and ranked them according to the preference order in respect of their significance for the research object, i.e. the most significant criterion has been assigned the highest value equal to one, the next criterion (according to its effect on the object of research) got the value of 2, etc.; the least significant index received value $m$, where $m$ is the number of the used criteria. The results of expert ranking are given in Table 4.

The findings provide a possibility of verifying if expert judgements are consistent. The level of consistency is defined by concordance coefficient $W$ introduced by M. Kendall [23, 24].

If expert estimates (data in Table 4) are marked as $e_{i k}$, thesum oftheranks of eachindexas $e_{i}=\sum_{k=1}^{r} e_{i k}$ andtheir total average as $\bar{e}=\frac{\sum_{i=1}^{m} e i}{m}(i=1,2, \ldots m ; k=1,2, \ldots, r)$, where $m$ is the number of criteria used, $r$ is the number of experts. 
Table 1 - The values of criteria for the P\&R parking lots of Group I

\begin{tabular}{|c|c|c|c|c|c|c|c|c|c|c|c||}
\hline $\begin{array}{c}\text { No. } \\
\text { of the } \\
\text { park- } \\
\text { ing lot }\end{array}$ & $\begin{array}{c}\mathrm{K}_{1}, \\
\text { thous. } €\end{array}$ & $\begin{array}{c}\mathrm{K}_{2}, \\
\text { veh/day }\end{array}$ & $\begin{array}{c}\mathrm{K}_{3}, \\
\text { number } \\
\text { of routes/ } \\
\text { peak-hour }\end{array}$ & $\begin{array}{c}\mathrm{K}_{4}, \\
\mathrm{~km} / \mathrm{h}\end{array}$ & $\begin{array}{c}\mathrm{K}_{5}, \\
\text { points }\end{array}$ & $\begin{array}{c}\mathrm{K}_{6}, \\
\text { points }\end{array}$ & $\begin{array}{c}\mathrm{K}_{7}, \\
€\end{array}$ & $\begin{array}{c}\mathrm{K}_{8}, \\
\text { points }\end{array}$ & $\begin{array}{c}\mathrm{K}_{9}, \\
\text { metres }\end{array}$ & $\begin{array}{c}\mathrm{K}_{10,} \\
€\end{array}$ & $\begin{array}{c}\mathrm{K}_{11}, \\
\%\end{array}$ \\
\hline \hline 1 & 4.6 & 1,280 & 17 & 25.4 & 3 & 2 & 0.29 & 2 & 17 & 0.58 & 3 \\
\hline 2 & 73.6 & 1,530 & 53 & 15.31 & 1 & 2 & 0.29 & 1 & 12 & 0.58 & 1.2 \\
\hline 3 & 73.6 & 2,400 & 64 & 23.52 & 1 & 2 & 0.29 & 1 & 11 & 0.58 & 3 \\
\hline 4 & 75.6 & 1,000 & 48 & 28.24 & 1 & 2 & 0.29 & 1 & 13 & 0.58 & 2 \\
\hline 5 & 75.6 & 1,510 & 4 & 14.74 & 1 & 2 & 0.29 & 2 & 30 & 0.58 & 3 \\
\hline 6 & 75.6 & 1,840 & 7 & 14.33 & 2 & 2 & 0.29 & 2 & 25 & 0.58 & 2.5 \\
\hline 7 & 72.1 & 2,630 & 37 & 22.06 & 1 & 2 & 0.29 & 2 & 18 & 0.58 & 2.5 \\
\hline 8 & 6.7 & 3,160 & 11 & 22.08 & 3 & 2 & 0.29 & 2 & 22 & 0.58 & 3 \\
\hline 9 & 72.7 & 2,110 & 9 & 30.66 & 1 & 2 & 0.29 & 2 & 24 & 0.58 & 3 \\
\hline 10 & 17.4 & 2,500 & 10 & 31.28 & 2 & 2 & 0.29 & 2 & 24 & 0.58 & 3 \\
\hline 11 & 4.6 & 1,700 & 18 & 20.16 & 2 & 2 & 0.29 & 2 & 11 & 0.58 & 3 \\
\hline 12 & 73.6 & 1,580 & 7 & 29.62 & 2 & 2 & 0.29 & 2 & 16 & 0.58 & 1.2 \\
\hline 13 & 73.6 & 850 & 5 & 32.53 & 1 & 2 & 0.29 & 1 & 7 & 0.58 & 3 \\
\hline 14 & 2.0 & 1,550 & 0 & 30.55 & 2 & 2 & 0.29 & 2 & 14 & 0.58 & 3 \\
\hline
\end{tabular}

Table 2 - The values of criteria for the P\&R parking lots of Group II

\begin{tabular}{|c|c|c|c|c|c|c|c|c|c|c|c||}
\hline $\begin{array}{c}\text { No. } \\
\text { of the } \\
\text { park- } \\
\text { ing lot }\end{array}$ & $\begin{array}{c}\mathrm{K}_{1}, \\
\text { thous. } €\end{array}$ & $\begin{array}{c}\mathrm{K}_{2}, \\
\text { veh/day }\end{array}$ & $\begin{array}{c}\mathrm{K}_{3}, \\
\text { number } \\
\text { of routes/ } \\
\text { peak-hour }\end{array}$ & $\begin{array}{c}\mathrm{K}_{4}, \\
\mathrm{~km} / \mathrm{h}\end{array}$ & $\begin{array}{c}\mathrm{K}_{5}, \\
\text { points }\end{array}$ & $\begin{array}{c}\mathrm{K}_{6}, \\
\text { points }\end{array}$ & $\begin{array}{c}\mathrm{K}_{7}, \\
€\end{array}$ & $\begin{array}{c}\mathrm{K}_{8}, \\
\text { points }\end{array}$ & $\begin{array}{c}\mathrm{K}_{9}, \\
\text { metres }\end{array}$ & $\begin{array}{c}\mathrm{K}_{10}, \\
€\end{array}$ & $\begin{array}{c}\mathrm{K}_{11} \text {, } \\
\%\end{array}$ \\
\hline \hline 15 & 4.6 & 2,500 & 25 & 26.33 & 2 & 2 & 0.58 & 2 & 22 & 0.58 & 3 \\
\hline 16 & 73.6 & 3,700 & 17 & 26.48 & 1 & 2 & 0.58 & 2 & 24 & 0.58 & 3 \\
\hline 17 & 73.6 & 6,380 & 38 & 24.37 & 1 & 2 & 0.58 & 2 & 28 & 0.58 & 2.5 \\
\hline 18 & 51.8 & 3,570 & 63 & 12.67 & 1 & 2 & 0.58 & 1 & 36 & 0.58 & 3 \\
\hline 19 & 73.6 & 6,400 & 20 & 20.58 & 2 & 2 & 0.58 & 2 & 25 & 0.58 & 2.5 \\
\hline 20 & 75.6 & 4,900 & 6 & 19.64 & 1 & 2 & 0.58 & 2 & 21 & 0.58 & 3 \\
\hline 21 & 4.6 & 3,320 & 39 & 11.90 & 3 & 1 & 0.58 & 2 & 31 & 0.58 & 3 \\
\hline 22 & 73.6 & 2,300 & 29 & 16.04 & 1 & 2 & 0.58 & 1 & 12 & 0.58 & 3 \\
\hline 23 & 75.6 & 2,170 & 47 & 23.23 & 1 & 2 & 0.58 & 1 & 18 & 0.58 & 2.5 \\
\hline 24 & 4.6 & 2,000 & 18 & 32.80 & 2 & 2 & 0.58 & 1 & 14 & 0.58 & 2.5 \\
\hline 25 & 80.5 & 2,020 & 42 & 21.68 & 2 & 2 & 0.58 & 1 & 18 & 0.58 & 2.5 \\
\hline 26 & 11.6 & 3,000 & 4 & 27.95 & 2 & 2 & 0.58 & 1 & 16 & 0.58 & 3 \\
\hline 27 & 4.6 & 6,380 & 3 & 26.82 & 3 & 2 & 0.58 & 2 & 21 & 0.58 & 2.5 \\
\hline
\end{tabular}

Table 3 - The values of criteria for the P\&R parking lots of Group III

\begin{tabular}{||c|c|c|c|c|c|c|c|c|c|c|c||}
\hline $\begin{array}{c}\text { No. } \\
\text { of the } \\
\text { park- } \\
\text { ing lot }\end{array}$ & $\begin{array}{c}\mathrm{K}_{1}, \\
\text { thous. } €\end{array}$ & $\begin{array}{c}\mathrm{K}_{2}, \\
\text { veh/day }\end{array}$ & $\begin{array}{c}\mathrm{K}_{3}, \\
\text { number } \\
\text { of routes/ } \\
\text { peak-hour }\end{array}$ & $\begin{array}{c}\mathrm{K}_{4}, \\
\mathrm{~km} / \mathrm{h}\end{array}$ & $\begin{array}{c}\mathrm{K}_{5}, \\
\text { points }\end{array}$ & $\begin{array}{c}\mathrm{K}_{6}, \\
\text { points }\end{array}$ & $\begin{array}{c}\mathrm{K}_{7}, \\
€\end{array}$ & $\begin{array}{c}\mathrm{K}_{8}, \\
\text { points }\end{array}$ & $\begin{array}{c}\mathrm{K}_{9}, \\
\text { metres }\end{array}$ & $\begin{array}{c}\mathrm{K}_{10}, \\
€\end{array}$ & $\begin{array}{c}\mathrm{K}_{11}, \\
\%\end{array}$ \\
\hline \hline 28 & 89.8 & 1,510 & 110 & 21.45 & 1 & 2 & 0.87 & 2 & 18 & 0.58 & 3 \\
\hline 29 & 80.5 & 2,100 & 30 & 23.93 & 1 & 2 & 0.87 & 1 & 11 & 0.58 & 3 \\
\hline 30 & 11.6 & 1,000 & 36 & 8.66 & 3 & 2 & 0.87 & 2 & 14 & 0.58 & 3 \\
\hline 31 & 11.6 & 2,800 & 20 & 24.26 & 3 & 3 & 0.87 & 2 & 27 & 0.58 & 3 \\
\hline 32 & 4.6 & 1,520 & 40 & 25.32 & 3 & 2 & 0.87 & 1 & 13 & 0.58 & 3 \\
\hline 33 & 73.6 & 2,470 & 47 & 24.60 & 1 & 2 & 0.87 & 1 & 17 & 0.58 & 2.5 \\
\hline
\end{tabular}


Table 4 - Results of expert ranking $e_{i k}$

\begin{tabular}{||l|l|c|c|c|c|c|c|c|c|c|c||}
\hline No & \multicolumn{1}{|c|}{ Expert Criterion } & 1 & 2 & 3 & 4 & 5 & 6 & 7 & 8 & $\begin{array}{c}\text { Expert } \\
\text { Criterion } e_{i}\end{array}$ & Position \\
\hline \hline 1 & Construction cost of P\&R parking lot & 10 & 10 & 7 & 5 & 5 & 4 & 4 & 4 & 49 & 6 \\
\hline 2 & Traffic volume & 7 & 9 & 9 & 7 & 4 & 3 & 3 & 2 & 44 & 4 \\
\hline 3 & Public transport network development & 1 & 4 & 1 & 2 & 2 & 1 & 1 & 1 & 13 & 1 \\
\hline 4 & $\begin{array}{l}\text { Centre accessibility by public } \\
\text { transport, speed }\end{array}$ & 2 & 1 & 4 & 1 & 1 & 2 & 2 & 5 & 18 & 2 \\
\hline 5 & Safety of P\&R parking lot & 4 & 2 & 6 & 9 & 8 & 11 & 8 & 10 & 58 & 7 \\
\hline 6 & Driver information system & 6 & 7 & 5 & 10 & 6 & 10 & 9 & 7 & 60 & 8 \\
\hline 7 & Parking fee for a car in the parking lot & 3 & 3 & 8 & 3 & 3 & 5 & 7 & 6 & 38 & 3 \\
\hline 8 & $\begin{array}{l}\text { Is the entrance to the parking lot } \\
\text { convenient? }\end{array}$ & 11 & 6 & 2 & 11 & 7 & 6 & 10 & 9 & 62 & 9 \\
\hline 9 & Street category & 9 & 8 & 11 & 6 & 9 & 7 & 11 & 11 & 72 & 11 \\
\hline 10 & $\begin{array}{l}\text { Integrated ticket fee for the parking } \\
\text { and using public transport }\end{array}$ & 5 & 5 & 3 & 4 & 11 & 9 & 6 & 3 & 46 & 5 \\
\hline 11 & Housing intensity & 8 & 11 & 10 & 8 & 10 & 8 & 5 & 8 & 68 & 10 \\
\hline
\end{tabular}

Concordance coefficient $W$ is calculated according to Formula [23, 24]:

$W=\frac{12 S}{r^{2} m\left(m^{2}-1\right)}$

The sum of squares $e_{i}$ of deviation from the total average $\bar{e}$ of values $S$ is defined by Formula

$S=\sum_{i=1}^{m}\left(e_{i}-\bar{e}\right)^{2}$

The level of the consistency of expert estimates is defined not by concordance coefficient $W$ itself but by related criterion $\chi^{2}$ calculated by Formula [23]

$\chi^{2}=W r(m-1)=\frac{12 S}{r m(m+1)}$

It has been proven [23] that when the value of $\chi^{2}$ calculated according to Formula 5 is higher than critical value $\chi_{k r}^{2}$ taken from the table of distribution $\chi^{2}$ with the degree of freedom $w=m-1$ and the selected significance level, $\alpha$ is close to zero, and a statistical hypothesis on the consistency of expert estimates is assumed.

With reference to Table 4, concordance coefficient $W=0.520$ has been calculated. Based on Formula 3 , the calculated value $\chi^{2}=41.61$ exceeds critical value $\chi_{\mathrm{kr}}^{2}=18.31$ with significance level $\alpha=0.05$ and freedom degree $v=11-1=10$. This shows expert judgements to be consistent.

On the basis of ranking, a possibility of determining the weights of criteria arises. A number of methods for establishing the weights of criteria have been worked out $[25,26]$. A general principle of estimation is that the most significant criterion is given the largest weight and usually the estimated weights are normalized, i.e.

$$
\sum_{i=1}^{m} \omega_{i}=1
$$

However, Table 4 shows criterion ranking where the most significant criterion has been given the smallest number - one. Therefore, ranking estimates $e_{i k}$ must be transformed in a way so that the most significant criterion got the largest estimate, for example, by the Formula

$c_{j k}=m-1-e_{i k}$

The most significant index (Rank 1) gets the highest value equal to $m$. Transformation results are given in Table 5.

Criterion weights can be calculated by Formula $\omega_{i}=\frac{c i}{\sum_{i=1}^{m} c_{i}}$

where $c_{i}$ is the normalized weight of the criterion.

The values of weights are also presented in Table 5.

\subsection{Establishment of the priority order of P\&R parking lots}

To estimate the development of three parking lots, three multiple-criteria methods, including SAW, TOPSIS and COPRAS have been used. Each method has different advantages and uses different ideas of data normalization and transformation. The SAW method embeds the core idea of multiple criteria decision-aid (MCDA) methods: to comprise weights of criteria and normalised values of criteria into a single cumulative criterion of the method. The TOPSIS method was chosen as it compares distances between weighted normalised values of criteria of an alternative to hypothetical worst and best alternatives. Both methods are very clear by logic and consequently are the best to choose. The COPRAS method was chosen, first, as a method which does not require transformation of values of minimising criteria; second, it was developed in Lithuania, and is popular in this country among researchers. Three methods were used simultaneously in order 
Table 5 - Transformed results and criterion weights of ranking

\begin{tabular}{||l|l|c|c|c|c|c|c|c|c|c|c||}
\hline No Expert Criteria & \multicolumn{1}{|c|}{1} & 2 & 3 & 4 & 5 & 6 & 7 & 8 & $\begin{array}{c}\text { The sum } \\
\text { of ranks } e_{i}\end{array}$ & Weights \\
\hline \hline 1 & Construction cost of P+R parking lot & 2 & 2 & 5 & 7 & 7 & 8 & 8 & 8 & 47 & 0.089 \\
\hline 2 & Traffic volume & 5 & 3 & 3 & 5 & 8 & 9 & 9 & 10 & 52 & 0.098 \\
\hline 3 & Public transport network development & 11 & 8 & 11 & 10 & 10 & 11 & 11 & 11 & 83 & 0.157 \\
\hline 4 & $\begin{array}{l}\text { Centre accessibility by public } \\
\text { transport, speed }\end{array}$ & 10 & 11 & 8 & 11 & 11 & 10 & 10 & 7 & 78 & 0.148 \\
\hline 5 & Safety of P+R parking lot & 8 & 10 & 6 & 3 & 4 & 1 & 4 & 2 & 38 & 0.072 \\
\hline 6 & Driver information system & 6 & 5 & 7 & 2 & 6 & 2 & 3 & 5 & 36 & 0.068 \\
\hline 7 & Parking fee for a car in the parking lot & 9 & 9 & 4 & 9 & 9 & 7 & 5 & 6 & 58 & 0.110 \\
\hline 8 & $\begin{array}{l}\text { Is the entrance to the parking lot } \\
\text { convenient? }\end{array}$ & 1 & 6 & 10 & 1 & 5 & 6 & 2 & 3 & 34 & 0.064 \\
\hline 9 & Street category & 3 & 4 & 1 & 6 & 3 & 5 & 1 & 1 & 24 & 0.045 \\
\hline 10 & $\begin{array}{l}\text { Integrated ticket fee for the parking } \\
\text { and using public transport }\end{array}$ & 7 & 7 & 9 & 8 & 1 & 3 & 6 & 9 & 50 & 0.095 \\
\hline 11 & Housing intensity & 4 & 1 & 2 & 4 & 2 & 4 & 7 & 4 & 28 & 0.053 \\
\hline
\end{tabular}

to comply with the principle of method triangulation, which is deemed to increase precision of evaluation.

The SAW (Simple Additive Weighting) method is the most widely used one in practice [27]. In this case, the sum of the weighted normalized values of all criteria is calculated considering each $j$-th parking lot. The criterion of method $S_{j}$ is calculated by the Formula

$S_{j}=\sum_{i=1}^{m} \omega_{i} \tilde{r}_{i j}$

where $\omega_{i}$ - the weight of the $i$-th criterion, $\tilde{r}_{i j}$ - the normalized value of the $i$-th criterion for the $j$-th parking lot.

The normalized values $r_{i j}$ of the SAW method are calculated by Formula

$r_{i j}=\frac{r_{i j}}{\sum_{j=1}^{n} r_{i j}}$

where ${ }^{j=1} r_{i j}$ the value of the $i$-th criterion for the $j$-th parking lot obtained from the table of expert estimates.

The main principle of the TOPSIS (Technique for Order Preference by Similarity to an Ideal Solution) method is based on the selection of the most optimum alternative having the smallest distance to ideal solutions and the largest distance to the worst solutions $[27,28,29]$. The method can be used both for maximizing (best values of which are the highest ones) and minimizing (best values of which are the lowest ones) criteria.

The TOPSIS method uses vector normalization:

$\tilde{r}_{i j}=\frac{r_{i j}}{\sqrt{\sum_{j=1}^{n} r_{i j}^{2}}} i=1, \ldots . m ; j=1, \ldots n$.

The best solution (alternative) $V^{\star}$ and the worst one $\checkmark$ are calculated by Formula

$V *=\left\{V_{1}^{*}, V_{2}^{*}, \ldots, V_{m}^{*}\right\}=\left\{\left(\max _{j} \omega_{i} r_{i j} / i \in I_{1}\right)\right.$

$\left.\left(\min _{j} \omega_{i} \tilde{r}_{i j} / i \in I_{2}\right)\right\}$;

(9) $\quad S_{-j}=\sum_{i=1}^{m} \omega_{-i} \tilde{r}_{-i j}$
$V=\left\{V_{1}, V_{2}, \ldots, V_{m}\right\}=\left\{\left(\min _{j} \omega_{i} r_{i j} / i \in I_{1}\right)\right.$,

$\left.\left(\max _{j} \omega_{i} \tilde{r}_{i j} / i \in I_{2}\right)\right\}$,

where $I_{1}$ - a set of the numbers of maximizing indices, $I_{2}$ - a set of the numbers of minimizing indices, $\omega_{i}$ - the weight of the $i$-th index $\left(\sum_{i=1}^{m} \omega_{i}=1\right)$.

The total distance of each compared alternative to best solutions $D_{j}^{*}$ and to worst solutions $D_{j}^{-}$is calculated by Formulas

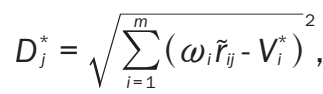

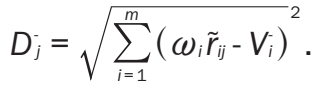

The evaluation criterion $C_{j}^{*}$ of the TOPSIS method is calculated by Formula

$C_{j}^{*}=\frac{D^{-}}{D_{j}^{*}+D_{j}^{-}}(j=1, \ldots, n)\left(0 \leq C_{j}^{*} \leq 1\right)$.

The best alternative corresponds to the highest value of criterion $C_{j}^{*}$. The compared alternatives must be ranked in a descending order.

The values of the evaluation criterion $Z_{j}$ of the COPRAS (Complex Proportional Assessment) method are determined by Formula

$Z_{j}=S_{+j}+\frac{\sum_{j=1}^{n} S_{i j}}{S_{-j} \sum_{j=1}^{n} \frac{1}{S_{-j}}}$

where

$S_{+j}=\sum_{i=1}^{m} \omega_{+i} \tilde{r}_{+i j}$

is the sum of maximizing weighted values $\tilde{r}_{+i j}$ normalized by Formula 9 for each $j-m$ alternative (parking lot); 
is the sum of the weighted normalized values of minimizing criteria $\tilde{r}_{i j} ; j=1,2, \ldots, n ; n$ - the number of compared alternatives; $S_{-\min }=\min S_{-j}-\operatorname{minimal} S_{-j}$ value of minimizing criteria of all álternatives. Symbol "+" shows that only the normalized values of the maximizing criteria of the $j$-th alternative $\tilde{r}_{+i j}$ multiplied by their weights $\omega_{+i}$ are summed up. Analogically, symbol “-“ corresponds to minimizing criteria and their weights $\omega_{-i}$.

The values of the evaluation criteria estimated by applying three multi-criteria methods, their positions and the final position are given in Tables 6-8. For additional ways of reporting results of MCDA evaluation please refer to [30].

\subsection{Analysis of the results of the priority order of $P \& R$ parking lots}

The estimation of group I of P\&R parking lots has revealed that, taking into account $14 \mathrm{P} \& \mathrm{R}$ parking lots, the first one would be ideal for the roundabout of public transport in Antakalnis area (Parking lot No. 3). The main reason for determining the first rank of this $P \& R$ parking lot is well-developed public transport with the frequency of 64 routes per hour. According to ranking, the second parking lot should be the one at the Gariūnai shopping centre (No. 8). The second rank of this lot has been established with reference to low construction cost and the average speed of public transport.

Table 6 - The values and positions of the P\&R parking lots of group I estimated applying multi-criteria methods

\begin{tabular}{|c|c|c|c|c|c|c|c|c|}
\hline \multirow{2}{*}{$\begin{array}{c}\text { Method } \\
\text { Parking } \\
\text { lot } \\
\end{array}$} & \multicolumn{2}{|c|}{ SAW } & \multicolumn{2}{|c|}{ COPRAS } & \multicolumn{2}{|c|}{ TOPSIS } & \multirow{2}{*}{$\begin{array}{c}\text { The sum of } \\
\text { positions of all } \\
\text { methods } \\
\end{array}$} & \multirow{2}{*}{ Position } \\
\hline & $\mathrm{S}_{j}$ & Position & $Z_{j}$ & Position & $C_{j}^{*}$ & Position & & \\
\hline 1 & 0.0822 & 3 & 0.0799 & 3 & 0.3992 & 6 & 12 & 3 \\
\hline 2 & 0.0714 & 9 & 0.0734 & 8 & 0.5838 & 2 & 19 & $6-9$ \\
\hline 3 & 0.0867 & 2 & 0.0887 & 1 & 0.6942 & 1 & 4 & 1 \\
\hline 4 & 0.0736 & 7 & 0.0755 & 7 & 0.5726 & 3 & 17 & 5 \\
\hline 5 & 0.0531 & 13 & 0.0550 & 13 & 0.1839 & 14 & 40 & $13-14$ \\
\hline 6 & 0.0573 & 12 & 0.0592 & 12 & 0.2147 & 13 & 37 & 12 \\
\hline 7 & 0.0756 & 6 & 0.0777 & 5 & 0.5230 & 4 & 15 & 4 \\
\hline 8 & 0.0809 & 4 & 0.0829 & 2 & 0.4042 & 5 & 11 & 2 \\
\hline 9 & 0.0640 & 10 & 0.0661 & 10 & 0.2986 & 10 & 30 & 10 \\
\hline 10 & 0.0725 & 8 & 0.0789 & 4 & 0.3784 & 7 & 19 & $6-9$ \\
\hline 11 & 0.0778 & 5 & 0.0756 & 6 & 0.3764 & 8 & 19 & $6-9$ \\
\hline 12 & 0.0595 & 11 & 0.0614 & 11 & 0.2581 & 11 & 33 & 11 \\
\hline 13 & 0.0520 & 14 & 0.0540 & 14 & 0.2377 & 12 & 40 & $13-14$ \\
\hline 14 & 0.0923 & 1 & 0.0709 & 9 & 0.3117 & 9 & 19 & $6-9$ \\
\hline
\end{tabular}

Table 7 - The values and positions of the P\&R parking lots of group II estimated applying multi-criteria methods

\begin{tabular}{||c|c|c|c|c|c|c|c|c||}
\hline \multirow{2}{*}{$\begin{array}{c}\text { Method } \\
\text { Parking } \\
\text { lot }\end{array}$} & \multicolumn{2}{|c|}{ SAW } & \multicolumn{2}{c|}{ COPRAS } & \multicolumn{2}{c|}{ TOPSIS } & $\begin{array}{c}\text { The sum of } \\
\text { positions of all } \\
\text { methods }\end{array}$ & Position \\
\hline \hline 15 & 0.0898 & 3 & 0.0855 & 3 & 0.4762 & 6 & 12 & $3-4$ \\
\hline 16 & 0.0688 & 10 & 0.0702 & 11 & 0.3333 & 12 & 33 & 11 \\
\hline 17 & 0.0824 & 5 & 0.0838 & 5 & 0.5429 & 3 & 13 & 5 \\
\hline 18 & 0.0812 & 6 & 0.0846 & 4 & 0.6218 & 1 & 11 & 2 \\
\hline 19 & 0.0752 & 7 & 0.0766 & 7 & 0.3906 & 9 & 23 & $8-9$ \\
\hline 20 & 0.0623 & 12 & 0.0635 & 12 & 0.2425 & 13 & 37 & $12-13$ \\
\hline 21 & 0.0923 & 1 & 0.0880 & 1 & 0.5448 & 2 & 4 & 1 \\
\hline 22 & 0.0609 & 13 & 0.0623 & 13 & 0.3381 & 11 & 37 & $12-13$ \\
\hline 23 & 0.0725 & 8 & 0.0738 & 8 & 0.5305 & 4 & 20 & 7 \\
\hline 24 & 0.0837 & 4 & 0.0794 & 6 & 0.4407 & 7 & 17 & 6 \\
\hline 25 & 0.0724 & 9 & 0.0732 & 9 & 0.4945 & 5 & 23 & $8-9$ \\
\hline 26 & 0.0672 & 11 & 0.0720 & 10 & 0.3413 & 10 & & 3 \\
\hline 27 & 0.0904 & 2 & 0.0861 & 2 & 0.4121 & 8 & 12 & 10 \\
\hline \hline
\end{tabular}


Table 8 - The values and positions of the P\&R parking lots of group III estimated applying multi-criteria methods

\begin{tabular}{||c|c|c|c|c|c|c|c|c||}
\hline \hline \multirow{2}{*}{$\begin{array}{c}\text { Method } \\
\text { Parking } \\
\text { lot }\end{array}$} & \multicolumn{2}{|c|}{ SAW } & \multicolumn{2}{c|}{ COPRAS } & \multicolumn{2}{c|}{ TOPSIS } & $\begin{array}{c}\text { The sum of } \\
\text { positions of all } \\
\text { methods }\end{array}$ & Position \\
\hline \hline 28 & 0.1831 & 3 & 0.1822 & 2 & 0.6231 & 1 & 6 & $1-3$ \\
\hline 29 & 0.1367 & 6 & 0.1372 & 6 & 0.3056 & 6 & 18 & 6 \\
\hline 30 & 0.1489 & 5 & 0.1562 & 4 & 0.3675 & 5 & 14 & 5 \\
\hline 31 & 0.1845 & 2 & 0.1918 & 1 & 0.4445 & 3 & 6 & $1-3$ \\
\hline 32 & 0.1943 & 1 & 0.1783 & 3 & 0.4719 & 2 & 6 & $1-3$ \\
\hline 33 & 0.1515 & 4 & 0.1533 & 5 & 0.4038 & 4 & 13 & 4 \\
\hline
\end{tabular}

The lowest ranks have been identified in Pilaitès Av. (No. 5) and Balsiai residential district (No. 13), which were caused by particularly rare frequency of public transport and high costs of installation.
The estimation of group II of P\&R parking lots have disclosed that, from the considered 13 P\&R parking lots, the first one would be ideal for Mada shopping centre (No. 21). The obtained result has been mostly influenced by the number of public transport routes

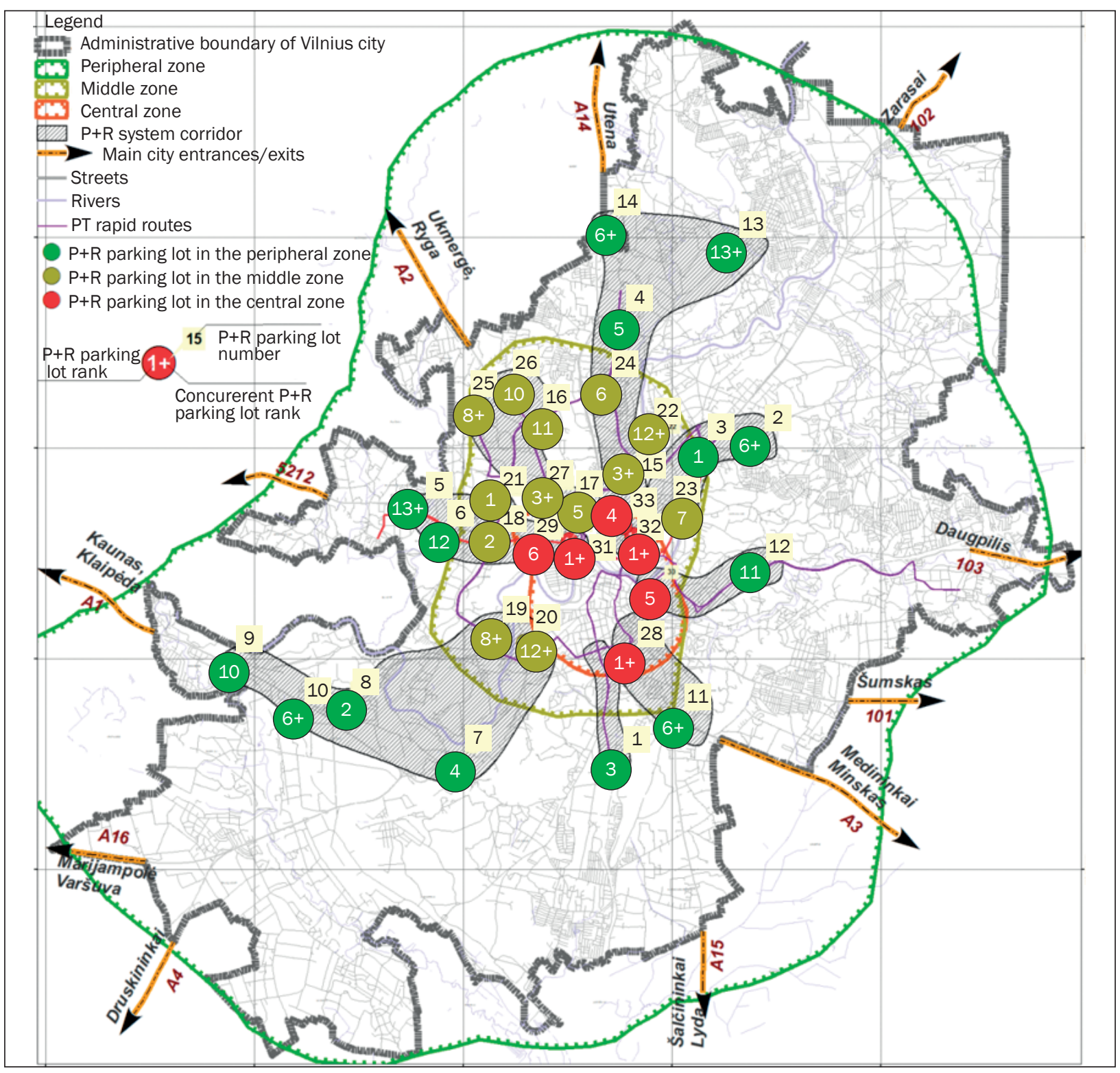

Figure 2 - Layout of P\&R parking lots in Vilnius City 
(39 routes per hour) and construction cost (4.6 thousand $€$ ). The second parking lot by the rank is the one at the Press House (No. 18), the second rank of which has been conditioned by a number of public transport routes amounting to 63 during the peak hour. The lowest ranks have been identified at New Acropolis (No. 20 ) and in the roundabout of public transport at the residential district of the North Town (No. 22). The main reason for the choice made is low speed of public transport (19.64 km/h and $16.04 \mathrm{~km} / \mathrm{h}$, respectively) and high construction cost (75.6 thousand $€$ and 73.6 thousand $€$, respectively).

The estimation of group III of P\&R parking lots have shown that, regarding 6 P\&R parking lots, the first three positions have been taken by the Station area (No. 28), Panorama shopping centre (No. 31) and Kalvariju market (No. 32). The lowest ranks of the P\&R parking lot have been identified in T. Kosciuškos Street near Vilnele River (No. 30) and in the roundabout of public transport in Žverrynas (No. 29). This has been caused by a rare frequency of public transport and huge construction costs.

The results obtained employing multi-criteria analysis methods are given in Tables 6-8 and Figure 2.

\subsection{Sampling system for P\&R parking lots}

The rank of the P\&R parking lot determined with the help of multi-criteria methods indicates what parking lots will be the most advantageous and disadvantageous for the city under specified conditions (Figure 2). The authors have focused on developing a high-quality scheme for P\&R parking lots that would bring well balanced benefits to the city in terms of economic, environmental and social sustainability.

Seeking this aim, the authors of the paper have identified eight possible corridors of the P\&R scheme and suggested a sampling strategy for P\&R parking lots. The designed strategy will form a competitive basis for public transport services in Vilnius City, which will help with reducing traffic flows in the central part of the city and assist in improving air quality and encouraging people to use public transport.

The sampling system of P\&R parking lots uses the following Formula suggested by the authors:

$K_{i}=\left(p_{i}+v_{i}+c_{i}\right) / n_{i}$,

where $K_{i}$ - the sum of ranks in the corridor, $p_{i}-$ number of $P \& R$ parking lots in the peripheral zone of the city, $v_{i}$ - number of P\&R parking lots in the middle zone of the city, $c_{i}-$ number of P\&R parking lots in the central zone of the city, $n_{i}-$ number of sampled P\&R parking lots in the corridor.

Having made the systemic sampling estimations of P\&R parking lots, the authors have distinguished eight stages indicating the development of the P\&R scheme (Table 9):

At stage I the P\&R scheme must be implemented in the communication corridor arranged in Kalvariju Street (Figure 3). The corridor will be made of the P\&R scheme for three parking lots one of which is planned in Santariškès, the peripheral area of the city, the second - in the middle zone of the city close to Siemens Arena and the third one - in the central zone of the city next to Kalvariju market.

At stage II, the P\&R scheme is planned in the communication corridor of the Airport where one P\&R parking lot will be opened at the International Vilnius Airport. Passenger flow will be diverted towards the Green (Žaliasis) Bridge.

At stage III, the P\&R scheme is planned in communication corridor A3 where two P\&R parking lots will be opened. The first parking lot will service the peripheral zone of the city at the Maxima shopping centre in

Table 9 - Sampling estimations for P\&R parking lots

\begin{tabular}{|c|c|c|c|c|c|c|c|}
\hline No. & $\begin{array}{l}\text { Communica- } \\
\text { tion corridor }\end{array}$ & $\begin{array}{c}\text { A number of } \\
\mathrm{P}+\mathrm{R} \text { parking } \\
\text { lots in a periph- } \\
\text { eral zone, } \mathrm{p}_{\mathrm{i}} \\
\end{array}$ & $\begin{array}{c}\text { A number of } \\
\mathrm{P}+\mathrm{R} \text { parking } \\
\text { lots in a middle } \\
\text { zone, } \mathrm{v}_{\mathrm{i}}\end{array}$ & $\begin{array}{c}\text { A number of } \\
\text { P+R parking } \\
\text { lots in a central } \\
\text { zone, } c_{i} \\
\end{array}$ & $\begin{array}{c}\text { A number of } \\
\text { samples } P+R \\
\text { parking lots, } n_{i}\end{array}$ & Sum of ranks & Position \\
\hline 1 & $\mathrm{~A} 1$ & 4 & 2 & 0 & 2 & 7.0 & VII \\
\hline 2 & 5212 & 2 & 2 & 2 & 3 & 5.0 & $\mathrm{~V}$ \\
\hline 3 & A2 & 0 & 5 & 0 & 2 & 5.5 & $\mathrm{VI}$ \\
\hline 4 & A14 & 3 & 3 & 2 & 3 & 3.0 & $|-I|$ \\
\hline 5 & 102 & 2 & 1 & 0 & 2 & 4.0 & IV \\
\hline 6 & 103 & 1 & 0 & 1 & 2 & 8.0 & VIII \\
\hline 7 & A3 & 1 & 0 & 1 & 2 & 3.5 & III \\
\hline 8 & Airport & 1 & 0 & 0 & 1 & 3.0 & $|-| \mid$ \\
\hline
\end{tabular}




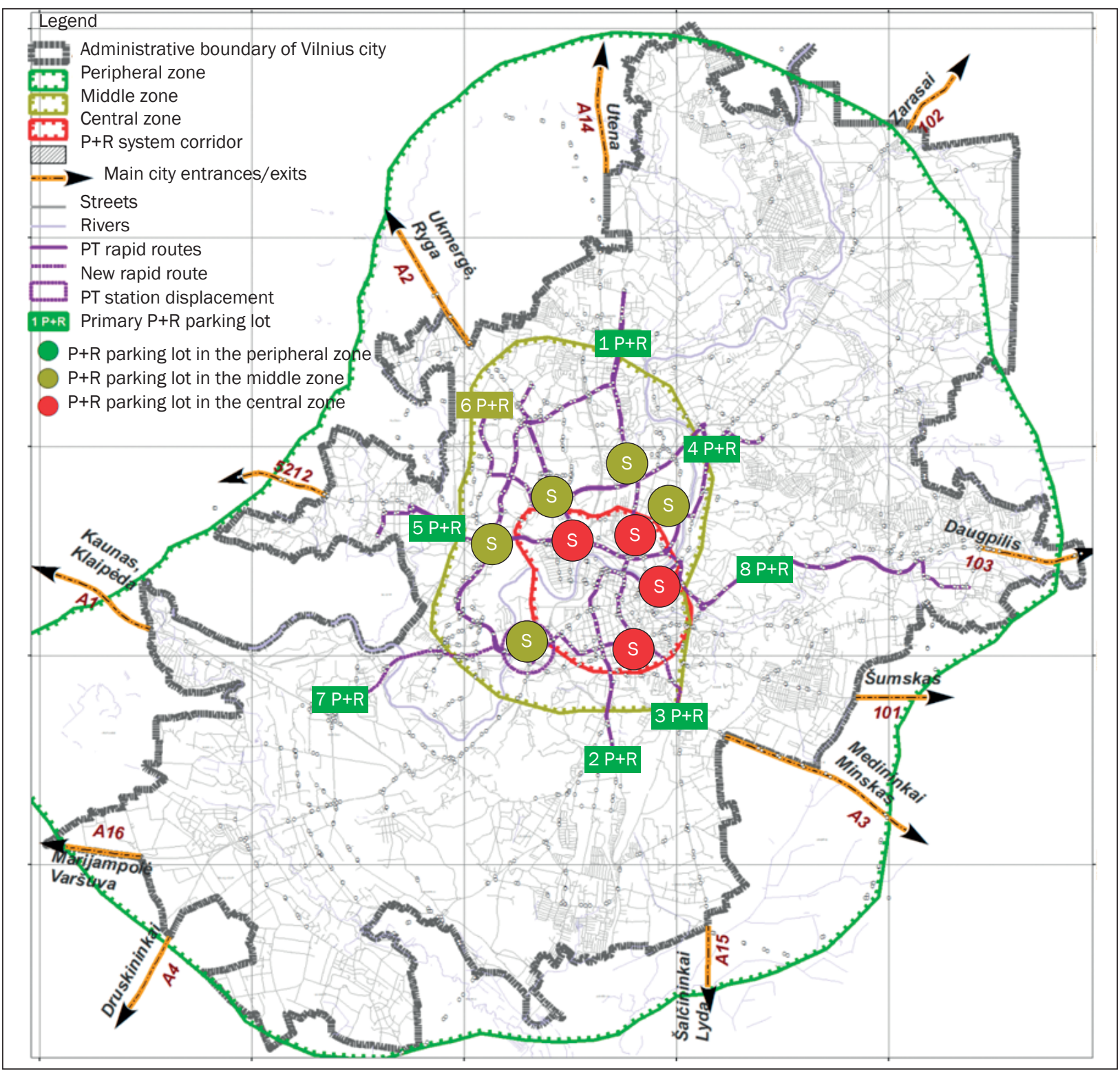

Figure 3 - Proposed system for P\&R parking lots

Liepkalnio Street. The second one will serve the central zone of the city at Bus and Railway Stations.

At stage IV, the P\&R scheme is planned to be implemented in the communication corridor of Antakalnio Street and will consist of two P\&R parking lots. The first parking lot is planned in the peripheral zone of the city - in the public transport roundabout in Antakalnis while the second one - in the middle zone of the city close to the Žirmūnai Bridge.

At stage $V$, the $P \& R$ scheme is planned to be implemented in communication corridor 5215 and will consist of three P\&R parking lots, the first of which is planned in the peripheral zone of the city at the old Pilaite road, the second one - in the middle zone of the city at the Press House, and the third - at Panorama shopping centre.

At stage $\mathrm{VI}$, the $\mathrm{P} \& \mathrm{R}$ scheme is planned to be implemented in communication corridor A2 that will include three P\&R parking lots. The first and second parking lots are planned in the middle zone of the city - in the public transport roundabout in Justiniškès and at the intersection of Ukmerges and Ozo Streets while the third one - at Panorama shopping centre.

At stage VII, the P\&R scheme is planned to be implemented in communication corridor A1 that will consist of two P\&R parking lots. The first parking lot is planned in the peripheral zone of the city at the shopping centre in Gariūnai, the second one - in the middle zone of the city at New Acropolis. It is important to mention that, under the implementation of a new P\&R parking lot at New Acropolis, the system of the bus stops of public transport must be reorganized.

At stage VIII, the P\&R scheme is planned to be implemented in communication corridor 103 that will embrace two P\&R parking lots. The first parking lot is planned in the peripheral zone of the city at St. Bato- 
ras intersection and the second one - in the central zone of the city in $T$. Kosciuškos Street near Vilnele River.

\section{CONCLUSIONS}

A range of policy measures is available to influence travel awareness. This long-term action means that P\&R planning can set the physical pattern upon which travel patterns are based for generations. There have been a fair number of EU studies concerning P\&R planning. Often, there is a complexity of local factors involved, relating to particular people and local institutions. It should be noted, that results and suggestions of this study are useful when solving complex urban development problems, and when preparing and justifying comprehensive plans or special transport plans.

In the course of the conducted scientific research, a methodology for selecting sites regarding P\&R parking lots has been developed which can be adapted and used not only in Lithuanian but also in cities abroad. The proper use of multi-criteria methods allows solving complex urban planning problems. In such problems inevitably conflicting criteria have to be considered in order to find a suitable solution. Finding consensus between expert opinions is another prominence of the methods, which is incorporated into the analysis framework. These considerations served for making a choice of the methods in favour of multi-criteria ones.

The results of the surveyed citizens show that the main problems of the city are related to transport and communication (59\%) and the living environment (36\%). It can be assumed that the number of residents in Vilnius will grow in the future. Therefore, a rise in the relative number of passenger cars is also expected. This shows that the issues concerning the city will only become more serious and the upcoming transport system will require major reorganization. In this case, the implementation of the P\&R scheme can be reviewed as one of the possibilities.

The analysis of scientific literature shows that the development of the P\&R scheme reduces traffic jams, enhances public transport viability and diminishes air pollution. The proposed approach of the authors is based on the multi-criteria method that enables analysis of the problem from a slightly different perspective than in the previous studies and to seek a systematic multi-objective approach from the point of urban and transport planning.

The estimation of the significance value of the criteria shows that their weight depends on expert experience, gained knowledge, the state of mind filling in the questionnaire and other circumstances. To select the main criteria for the P\&R scheme, eight experts having at least ten- year experience in the field of transport have been chosen. Expert estimates of criteria weights have suggested that the greatest significance has been determined in the fields of public transport development (0.157), accessibility (access speed) to the city centre by public transport $(0.148)$ and parking fee in the P\&R parking lot (0.110).

Prior to calculations made by applying multi-criteria methods, the planned $P \& R$ parking lots in Vilnius City were divided into three groups according to the zones of the city: the peripheral zone of the city (14 P\&R parking lots planned), the middle zone of the city (13 P\&R parking lots planned) and the central zone of the city ( 6 P\&R parking lots planned).

The analysis of the obtained results has shown that on the city scale, the rank of the P\&R parking lot is mainly affected by the development level of public transport $\omega_{1}=0.157$ and the speed of public transport $\omega_{1}=0148$. An absolute priority to the implementation of P\&R parking lots in Vilnius City have been taken by the roundabout in Antakalnis (Parking lot 3), Mada shopping centre (Parking lot 21) and the Station area (Parking lot 28).

The P\&R scheme in Vilnius must be integrated into the common system of public transport of the city applying the principle of the corridor. A priority order of P\&R parking lots established with reference to multi-criteria methods allowed the authors to suggest a strategy for sampling with the help of which the most perspective corridor for implementing the P\&R scheme (A14) has been determined. A strategy for the sampling system for the corridors is based on the formula developed by the authors. More sophisticated MCDA methods could be used in the future research in such cases when reducing the effects of uncertainty in the data is required [31] or absolute evaluation of objects should be performed [32].

VYTAUTAS PALEVIČIUS, PhD.

E-mail: vytautas.palevicius@vgtu.lt

VYTAUTAS GRIGONIS, PhD.

E-mail: vytautas.grigonis@vgtu.It

ASKOLDAS PODVIEZKO, PhD.

E-mail: askoldas@gmail.com

GRETA BARAUSKAITÉ, MSc.

E-mail: greta.barauskaitė@vgtu.It

Vilniaus Gedimino technikos universitetas

Aplinkos inžinerijos fakultetas

Verslo vadybos fakutetas

Saulètekio al. 11, LT-10223 Vilnius, Lithuania

\section{SANTRAUKA}

Sparčiai augantis automobilizacijos lygis Lietuvos miestuose, o ypač Vilniaus mieste, sukèlè nuolatines grūstis gatvèse, atitinkamai padidejo neigiamas transporto poveikis, išaugo finansinių ir žemès išteklių poreikis. Aukštas automobilizacijos lygis reikalauja didelių susisiekimo infrastruktūros resursų, todèl miestuose turi būti sudarytos sąlygos plètotis darniai miesto susisiekimo infrastruktūrai, kuri tenkintu gyventoju poreikius. Vilniaus miesto savivaldy- 
bės administracija 2014-2020 Europos Sajungos struktūrinès paramos periode numato teikti paraišką gauti finansavimą "Statyk ir važiuok" sistemos diegimui Vilniaus mieste. Šio straipsnio tikslas - sukurti „Statyk ir važiuok“ aikštelių vietų parinkimo daugiakriterinę metodiką ir atlikti „Statyk ir važiuok“ aikštelių plètros analizę sukuriant tokių aikštelių sistemą Vilniaus mieste. Darbe taikytas ekspertinis metodas, kurio pagrindu nustatyti „Statyk ir važiuok“ aikštelių plètrai pagrindiniai kriterijai. Ekspertinès apklausos metu nustatyti kriteriju svoriai ir reikšmingumas. Daugiakriteriniais metodais apskaičiuoti ir pateikti plètros prioritetai bei pasiūlymu igyvendinimo strategija.

\section{RAKTINIAI ŽODŽIAI}

daugiakriteriai metodai; "statyk ir važiuok" schema; miesto struktūros planavimas; viešasis transportas;

\section{REFERENCES}

[1] Grigonis V, Burinskiene M, Paliulis G, Uspalyte-Vitkuniene R, Dumbliauskas V, Barauskas A. Modelling a passenger car system based on the principles of sustainable mobility in Vilnius City. Transport. 2014 Sep;29(3):334-341.

[2] Burinskiene $M$, Uspalyts-Vitkuniene $R$, Tuminiene F. Public Transport Integration into Urban Planning. The Baltic Journal of Road and Bridge Engineering. 2011;6(2):84-90.

[3] Hickman R, Hall P, Banister D. Planning more for sustainable mobility. Journal of Transport Geography. 2013 Dec;33:210-219.

[4] Noel EC. Park-and-ride: alive, well, and expanding in the United States. Journal of Urban Planning and Development. 1988 June;114(1):2-13.

[5] Wang JY, Yang H, Lindsey R. Locating and pricing parkand-ride facilities in a linear monocentric city with deterministic mode choice. Transportation Research Part B: Methodological. 2004 Sep;38(8):709-731.

[6] Štefančić G, Šarić S, Spudić R. Correlation between Land Use and Urban Public Transport: Case Study of Zagreb. Promet - Traffic \& Transportation. 2014 Apr;26(2):179-184.

[7] Dijk M, de Haes J, Montalvo C. Park-and-Ride motivations and air quality norms in Europe. Journal of Transport Geography. 2013 June;30:149-160.

[8] Liu Z, Meng Q. Bus-based park-and-ride system: a stochastic model on multimodal network with congestion pricing schemes. International Journal of Systems Science. 2014;45(5):994-1006.

[9] Du B, Wang DZ. Continuum modeling of park-and-ride services considering travel time reliability and heterogeneous commuters - A linear complementarity system approach. Transportation Research Part E: Logistics and Transportation Review. 2014 Nov;71:58-81.

[10] Wang H, Meng Q, Zhang XN. Park-and-Ride Network Equilibrium with Heterogeneous Commuters and Parking Space Constraint. Transportation Research Record: Journal of the Transportation Research Board. 2014;2466:87-97.
[11] Clayton W, Ben-Elia E, Parkhurst G, Ricci M. Where to park? A behavioural comparison of bus Park and Ride and city centre car park usage in Bath, UK. Journal of Transport Geography. 2014 Apr;36:124-133.

[12] Yushimito WF, Aros-Vera F, Reilly JJ. User rationality and optimal park-and-ride location under potential demand maximization. Transportation Research Part B: Methodological. 2012 Sep;46(8):949-970.

[13] Dickins IS. Park and ride facilities on light rail transit systems. Transportation. 1991 Mar;18(1):23-36.

[14] Mingardo G. Transport and environmental effects of rail-based Park and Ride: evidence from the Netherlands. Journal of Transport Geography. 2013 June;30:7-16.

[15] Meek S, Ison S, Enoch M. UK local authority attitudes to Park and Ride. Journal of Transport Geography. 2010 May;18(3):372-381.

[16] Chen G, Zhou YJ, Cheng JX. Evaluation on the relative transfer efficiency of urban peripheral park and ride facilities. Journal of Traffic and Transportation. 2005 Jan; 7:10-13.

[17] Parkhurst G. Influence of bus-based park and ride facilities on users' car traffic. Transport Policy. 2000 Apr;7(2):159-172.

[18] Basarić V, Mitrović J, Papić Z. Passenger car usage for commuting to work as a function of limited stay at car parks. Promet - Traffic \& Transportation. 2013 May;25(4):323-330.

[19] Farhan B, Murray AT. Siting park-and-ride facilities using a multi-objective spatial optimization model. Computers \& Operations Research. 2008 Feb;35(2):445456.

[20] Khakbaz A, Nookabadi AS, Shetab-bushehri SN. A Model for Locating Park-and-Ride Facilities on Urban Networks Based on Maximizing Flow Capture: A Case Study of Isfahan, Iran. Networks and Spatial Economics. 2013 Mar;13(1):43-66.

[21] Fan W, Khan M, Ma J, Jiang X. Bilevel Programming Model for Locating Park-and-Ride Facilities. Journal of Urban Planning and Development. 2014 Sep;140(3):04014007.

[22] Zavadskas EK, Turskis Z, Kildiene S. State of art surveys of overviews on MCDM/MADM methods. Technological and Economic Development of Economy. 2014 Mar;20(1):165-79.

[23] Kendall M. Rank correlation methods. London: Griffin; 1970.

[24] Podvezko V. Agreement of expert estimates. Economic Development of Economy. 2005;11(2):101-7.

[25] Saaty TL. The Analytic Hierarchy Process. New York: McGraw Hill; 1980.

[26] Podvezko V, Sivilevicius $\mathrm{H}$. The use of AHP and rank correlation methods for determining the significance of the interaction between the elements of a transport system having a strong influence on traffic safety. Transport. 2013 Dec;28(4):389-403.

[27] Hwang CL, Yoon K. Multiple Attribute Decision Making Methods and Applications. Berlin: Springer-Verlag; 1981.

[28] Opricovic S, Tzeng G-H. Compromise solution by MCDM methods: A comparative analysis of VIKOR and TOPSIS. European Journal of Operational Research. 2004 July;156(2):445-55. 
[29] Brauers W, Ginevicius R, Podviezko A. Development of a methodology of evaluation of financial stability of commercial banks. Panoeconomicus. 2014;61(3):349-67.

[30] Podviezko, A. Augmenting multicriteria decision aid methods by graphical and analytical reporting tools. In: Workshops on Business Informatics Research. Springer Berlin Heidelberg, 2012; p. 236-51.

[31] Podvezko V, Podviezko A. Use and Choice of Preference Functions for Evaluation of Characteristics of Socio-Economical Processes. In: Ginevicius R, Rut- kauskas AV, Pocs R, editors. 6th Int. Sci. Conf. Bus. Manag. Sel. Pap. Vilnius, Lithuania: Technika, 2010; p. 1066-71.

[32] Podviezko A, Podvezko V. Absolute and Relative Evaluation of Socio-Economic Objects Based on Multiple Criteria Decision Making Methods. Engineering Economics. 2014;25(5):522-9. 